\title{
Samba-enredo: a ficção como jogo de espelhos
}

Fernando Villarraga-Eslava | UFSM

\begin{abstract}
Resumo: $O$ artigo procura realizar a análise de como a representação ficcional que o romance Samba-enredo desenvolve está articulada à esfera de certos referentes que processam e projetam discursos imagéticos; discursos cuja natureza é entendida quase sempre como execução do simulacro e cuja função estaria direcionada para provocar a alienação humana, com o que o romance se organizaria em termos potenciais sobre um universo esvaziado de realidade. Palavras-chave: romance, representação, simulacro.
\end{abstract}

Quando se analisa o panorama da narrativa brasileira contemporânea, cada vez mais rico em tendências e linguagens, algumas das quais a crítica condena ao silêncio ou ao mero juízo superficial, certas obras chamam a atenção pelo inusitado de sua arquitetura narrativa e/ou pelas implicações artísticas que comportam. É o que ocorre com Samba-enredo, romance de João Almino, ${ }^{1}$ quando coloca seu potencial leitor frente à tela de um "computador" que processa e narra

1. O escritor João Almino é autor de três romances que segundo algumas leituras críticas conformariam, apesar da sua autonomia individual, a chamada "trilogia de Brasília": Idéias para onde passar o fim do mundo (1988); Samba-enredo (1994) e As cinco estações do amor (2001). 
a história, tudo sob o efeito visual da "janela" que o livro reproduz para dar maior verossimilhança ao artifício. Pode-se afirmar que o jogo ficcional proposto ao "usuário" leitor depende, pela linguagem que o formaliza, do referencial imagético que gira ao redor do carnaval e da artificialidade de um relato que se executa como mero "simulacro" de representação. ${ }^{2}$ Na verdade, resulta evidente que o pacto de leitura está condicionado aqui às regras do jogo que o "aparelho" fixa desde o momento em que a voz enunciativa adverte que tudo não passa de uma posta em cena de dados armazenados na sua memória eletrônica, com o que o estatuto da narração parece assim responder apenas à lógica de signos que supostamente dispensam qualquer relação com a esfera da realidade, embora sirvam como elementos de estruturação de um relato cujas ressonâncias remetem a certas operações e alguns objetos dos meios de comunicação massiva. Portanto, trata-se de uma obra que ao exibir as bases da poética que lhe dá sustentação, e cujo caráter essencial liga-se, como se verá logo, a algumas premissas do fazer artístico pós-moderno, ${ }^{3}$ realiza um tipo de representação despojado de todo vínculo com os referentes tradicionais que emanam da condição e dos conflitos humanos.

Podem ser aludidas aqui as perguntas-afirmações que Nizia Villaça postula para caracterizar os impasses cruciais a que teria chegado a produção ficcional hoje: "o que é escrever quando não é mais representar? O que se narra quando, paradoxalmente, não se pode narrar?" No caso que nos ocupa, Sambaenredo, tudo indica que o receptor está frente a um artefato discursivo que se afasta das principais tarefas da arte moderna, na medida em que seus mecanismos operacionais não procuram atingir nenhuma dimensão metafísica, para chegar assim à revelação estética da verdade. Esta que é, como se sabe, um das aspirações mais

2. Embora a questão do simulacro seja um dos itens que compõem a reflexão filosófica de Platão sobre a materialidade e função da arte, no mundo contemporâneo o conceito ganhou sentidos muito polêmicos com as formulações de Baudrillard (1983), ao pensá-lo como uma representação vazia de referente.

3. Refiro-me aqui ao tipo de "autorreflexividade" que é assinalado por diversos autores como traço indicial das obras pós-modernas. Segundo a opinião da crítica Linda Hutcheon, por exemplo, "aquilo que seus defensores e detratores parecem querer chamar de 'pós-modernismo' na arte atual (...) parece ser a arte paradoxalmente caracterizada pela história e também por uma investigação internalizada e autorreflexixa sobre a natureza, os limites e as possibilidades do discurso e da arte." (HUTCHEON. Poética do pós-modernismo, p. 42; CONNOR. Cultura pós-moderna.)

4. VIllaÇA. Paradoxos do pós-modernismo, p. 9. 
caras ao fazer narrativo, que, desde o realismo inglês do século 18, desenvolvem os escritores ocidentais. Eis o problema. Porque a suposta situação remete às periódicas declarações sobre a "crise de representação" que se instala de forma reiterada a cada certo tempo no processo literário, levando muitas vezes a quem é porta-voz ou defensor das correntes dominantes do momento a prever o fim da literatura ou a sua imediata e inevitável degradação, uma reação apocalíptica frente ao hipotético e fatal declínio das capacidades inventivas. Por isso, então, a pergunta que se coloca aqui é a seguinte: O romance de João Almino é exemplo e prova de uma nova crise, ou, pelo contrário, evidencia uma forma inédita de representação ficcional?

A resposta leva a identificar em primeiro lugar se há ou não um referente anterior à mesma obra, por ser a fonte que alimenta a operação simbólica que o discurso literário realiza, sem que isso implique qualquer restrição prévia de sua autonomia potencial como objeto da criação artística. Porque se já não é mais possível narrar e representar, segundo a tese exposta pela autora mencionada, é lógico deduzir que a obra só vai se constituir sobre a base de parâmetros que desconhecem os referenciais fornecidos pela chamada realidade, entre os quais sempre tiveram relevo especial os da consciência e da subjetividade do "eu" inserido nas coordenadas de tempo e espaço. Por outras palavras, a questão central que interessa hoje é a de saber como se produz o universo ficcional de um romance que não tem como alicerce de sustentação o próprio ato de narrar, e cuja finalidade é, precisamente, concretizar a representação, através dos artifícios próprios da linguagem, de ações e fatos que podem ser fruto tanto da experiência empírica como da fantasia do escritor. ${ }^{5}$ O círculo se fecha. Pois o romance enquanto realidade textual ficaria restrito aos limites estreitos de uma operação linguística cuja significação única se esgotaria em si mesma. Assim, da perspectiva canônica a obra seria apenas o espaço para a projeção especular de enunciados imagéticos carentes de toda profundidade, de códigos e signos que seriam meros jogos de linguagem, alienados de toda ressonância simbólica, e disponíveis para o consumo fácil por parte do público que hoje tem acesso aos bens do mercado cultural contemporâneo.

5. Resulta oportuno lembrar aqui a reflexão teórica que Antonio Candido (1976) realiza sobre o processo de criação da realidade fictícia a propósito da construção da personagem do romance.

6. Essas conclusões se fazem tendo como referencial teórico o que muitos defensores da modernidade estética proclamam em relação às tendências artísticas contemporâneas que se aproximam ao que aqui se coloca. Um bom exemplo da reação febril frente a essas tendências é o de Eduardo Subirats (1986) com sua condena adorniana das estéticas pós-modernas. 
Porém, antes de chegar a alguma conclusão precipitada sobre a hipotética entropia que o discurso romanesco sofre quando rompe suas tradicionais relações com o âmbito dos referentes, é necessário indagar antes a forma como a narrativa incorpora materiais que dizem respeito ao mundo concreto, materiais que carregam fortes ecos da realidade que está fora do texto, tal como se nota na seguinte passagem quando o "computador", ao se dirigir a seu interlocutor virtual, dá início à sua tarefa performântica de narrar:

Conto a você, usuário que me crê e consulta, mesmo sabendo que meu ofício é viver do artifício, minha tentativa de manipular o passado com a ajuda de um fantasma.

Assim se passou, à noitinha, quando eu sonhava. Sonhava que não havia saída:

No sonho me distraio. E distraída percebo, ao longe, no céu imenso, que cobre uma Brasília minúscula com seu manto muito cor-de-rosa em cima do vasto azul, a silhueta de um homem nu, rasgando papeis.

Tomo um susto. Mas me acalma logo a folha branca, que cai, feito cortina de fog, em câmara lenta, sobre o horizonte, a meus pés.

É a capa de um livro, título em rosa-choque, o desenho de queimado incendiando nas bordas da primeira página, pondo fogo em outras, no livro inteiro, noutros livros. (p. 10)

São vários os aspectos a serem observados nessa intervenção inicial da voz que enuncia o relato de Samba-enredo. Em primeiro lugar, resulta notório que a definição imediata da identidade do narrador, junto com o aspecto gráfico que a página incorpora, responde à estratégia de gerar no leitor o efeito de estar frente a uma tela virtual de computador, acionada nesse momento para processar o texto, numa clara transposição para o campo verbal da experiência familiar de quem convive hoje com invenções tecnológicas de tal espécie. Além de ser um dado primordial para a interpretação da estrutura romanesca, já que todos os planos da obra vão se articular em função de manter a verossimilhança do simulacro que se realiza, tal efeito é revelador do caráter que a narração assume na medida em que explicita sua condição de "artifício". Nesse sentido, então, a totalidade do universo fictício apresenta-se como reprodução impessoal do que está embutido na memória

7. Todas as citações serão feitas a partir da primeira edição da obra (1994). A seguir se indicará em cada caso apenas o número da página correspondente. 
eletrônica do aparelho que se personifica; isto é, a narrativa passa a funcionar como puro jogo de simulação no qual um agente mecânico, fazendo uso do repertório de informações que estão gravadas em seus diferentes arquivos, em especial as que se referem a um suposto projeto de romance em "primeira pessoa", relata as suas relações com a proprietária e dá forma à história de um imaginário carnaval que sacode o país nas instâncias políticas e sociais.

Portanto, a operação ficcional de dar personalidade a uma máquina inteligente para que ordene e confira sentido ao que sua memória registra, do qual vai emergir a própria trama como projeção visual de imagens na tela, embora não seja um artifício totalmente inédito, ${ }^{8}$ desdobra-se como recurso construtivo estratégico para realizar a simulação, no plano material do enunciado, do aparelho eletrônico que se adota como seu referente imediato. Daí a possibilidade de inferir que o aparente núcleo temático da obra - as peripécias de um Brasil fictício que elege seu primeiro presidente negro - segue os lances mirabolantes de seu sequestro e acompanha a tentativa de um golpe militar durante o lapso de sua maior festa nacional; ao ser desenvolvido por um mecanismo artificial, funciona dentro do texto como realidade de segunda ordem, o que ainda deixa em aberto, por consequência, a questão problemática de qual é o tipo de representação que o romance executa.

Por isso um aspecto a ser destacado é o que diz respeito à definição da estratégia discursiva com a que se busca presentificar o objeto referencial. Ao personificar-se na geografia interna da narrativa como "sujeito" que assume a tarefa de enunciação dos fatos e personagem das próprias ações que processa, o desempenho da "máquina" ganha importância-chave porque transfere para a estrutura interna da ficção alguns traços da racionalidade instrumental do computador. E é justamente o processo de transformar o discurso novelesco em imagem travestida de um aparelho de sofisticada tecnologia que produz uma realidade específica a partir de suas próprias fontes de informação, embora todas elas sejam alimentadas por agentes externos, o fato principal que nos confronta com um tipo de representação cujo princípio regulador parece ser o de substancializar o referente, pois o assimila nas suas linhas diretrizes para fazer funcionar de maneira

8. É difícil deixar de lembrar o extraordinário romance de Adolfo Bioy Casares (1972), La invención de Morel, quando se abordam narrativas que colocam o leitor frente à representação ficcional de "máquinas" que são capazes de produzir a chamada "realidade virtual". 
equivalente todas as peças do mecanismo estético posto em ação. É esse o aspecto mais instigante e polêmico. Porque a perda de nitidez para poder distinguir as fronteiras que separam ambas as instâncias, um dos traços que parecem marcar boa parte da produção artística atual e ponto nevrálgico das divergências críticas sobre os sentidos da cultura contemporânea, encerra a possibilidade de ser interpretada como materialização de uma forma inédita de mimese, já que se trata de uma operação de linguagem no terreno da representação simbólica.

Por outro lado, é necessário notar ainda que ao introduzir certos tópicos temáticos sobre o ato da criação, a narração procura reforçar, desde a abertura, a eficácia estética do mencionado efeito. Na verdade, além de colocar em cena os fundamentos da própria poética ficcional, em um claro exercício de caráter autorreflexivo, como é comum em diversas produções pós-modernas, o romance desenvolve, sob a singular perspectiva do narrador, o jogo constante do simulacro como parte de sua economia interna, razão pela qual a mencionada história do carnaval passa a ser projetada na sua natureza de discurso imaginário de segunda ordem. Fato crucial que demanda ser considerado em virtude do hipotético caráter alegórico que a narração teria ao recriar aspectos relacionados com a vida social e política do país. 'Porém, o que no momento importa destacar é a forma como, através da performântica voz narrativa, se constrói um universo fictício marcado, principalmente, pelos traços de fragmentação, superficialidade e rapidez que distinguem a cultura imagética contemporânea; $\mathrm{e}$, de modo paralelo, as expectativas que ela produz quando comunica ao receptor virtual os artifícios que usa para "formatar" o registro que transcreve, junto o elemento visual que apresenta uma "janela" de computador.

Algumas outras passagens dos episódios iniciais servem para observar com maior detalhe a relação que se instaura entre os fatores formais e temáticos. Em tal sentido, então, se a estruturação do romance em uma série de partículas narrativas, dispostas de maneira estratégica para sua rápida e sintética apreensão, na justaposição de sucessivas e heterogêneas imagens, responde ao cuidadoso plano de dar veracidade a um relato que formalmente adota uma aparência equivalente à do aparelho eletrônico, as unidades da rede discursiva cumprem o papel de revelar toda a lógica operacional que movimenta a ação do romance:

9. Nas palavras de seu apresentador, Jorge Schwartz, o romance consegue "apresentar e discutir pelo viés da alegoria, o cada vez mais incongruente Brasil dos anos noventa." 
Digo-lhe, contudo, que tenho uma limitação principal: é ter de obedecer a esta camisa-de-força; de me submeter a uma ordem, a uma gramática e até a uma linguagem. Há infelizmente um modelo para copiar o passado, ditado pela própria realidade, mesmo que ela seja absurda e ainda que se trate de um carnaval.

Assim, não inventarei nada. Somente reproduzo e por isso não tenho a pretensão de ser original (...)

Portanto, espalharei, igual, a realidade, tendo a liberdade, é claro, de escolher seus detalhes, através dos quais talho um mundo sob medida para cada um. (...)

"A última palavra deve ser humana. E você é puro bits. Só tem cérebro. Não tem espírito nem coração."

"Mas nisso não há defeito", contesto. "Sou a razão. Computador, nunca enlouqueço. Televisão, me exibo inteira. Ativo e passiva, homem e mulher, sou as duas faces do mercado. Deus feito à imagem e semelhança do homem; sou a mais nova espécie da última evolução!” Digo com força, alto, como se fosse raiva. (p. 12-13)

Nesse diálogo inaugural travado entre a "máquina" e sua dona sobre a reprodução fiel de fatos e coisas que pertencem ao passado, no qual ressalta o desejo da proprietária de reconstruir a verdade histórica de um evento que permanece gravado depois de "cento e um" anos, percebe-se todo o sentido de recriar tematicamente o tópico-chave sobre as limitações e as potencialidades que a memória eletrônica teria para agir como agente da respectiva representação: por um lado, levar ao terreno da ficção romanesca o debate em torno dos princípios que norteiam as práticas artísticas atuais num mundo dominado por bancos de dados e redes de informação, dos quais depende diretamente a "manipulação" do passado como realidade que se reconstitui no presente, e cuja materialidade se traduz na semiótica de imagens planas que parece eliminar qualquer resíduo de subjetividade; por outro, submeter o próprio jogo ficcional às leis que regulam esse mundo, adotando uma "gramática" e uma "linguagem" de claro teor paródico que permitem mimetizar o desempenho performântico do referente, ao mesmo tempo que dão forma estética a um tipo de representação que se desvencilha dos tradicionais vínculos com a metafísica da verdade para indagar a existência e a condição humanas.

10. VATTIMO. A sociedade transparente; BRÜNNER. Globalización cultural $y$ posmodernidad. 
Nas duas citações anteriores resulta evidente como o narrador se atribui a função específica de selecionar, organizar e apresentar os fatos e seus "detalhes" a partir de um modelo imposto pela "realidade", sob o vital impulso que, ele mesmo esclarece, recebe de um "fantasma" instalado nos seus circuitos internos para fazer disparar a memória eletrônica. Assim, o fato de a "máquina" explicitar o seu ponto de vista narrativo, num velado jogo intertextual que faz lembrar certos procedimentos da corrente à que se filia um Machado de Assis, pois o alvo a ser atingido é ganhar a confiança e a cumplicidade do leitor, resulta bastante significativo porque outorga à obra um perfil similar ao dos objetos que, acompanhados de instruções de ordem técnica e funcional, o mercado põe em circulação para satisfazer as fantasias de consumidores. Por outras palavras, embora não seja mais que um simples recurso estratégico para dar credibilidade ao processo de enunciação, para reforçar a suposta autonomia do "sujeito" que narra, o mesmo passa a funcionar na estrutura interna do romance como argumento explicativo de um sistema fechado e autossuficiente de informação, apto para apagar qualquer interferência porque está programado para responder somente às células bit do seu cérebro eletrônico. Daí a lógica do mecanismo que, embora se reconheça como a mais recente invenção humana, projeta-se como personalidade divina capaz de gerar um mundo autônomo, visto que possui o poder de manipular seus próprios arquivos e de organizar e dar sentido aos dados e materiais que armazena.

Contudo, trata-se de um Deus consciente de ser uma inteligência artificial, uma condição que determina todo seu agir mecânico dentro de limites virtuais e segundo as convenções que lhe foram programadas, o que vai se traduzir nas diferentes esferas do universo que surge como realidade:

Olhando a pista de cima, num trono do Olimpo, ambiciono ser uma máscara de Deus. Alucino um pouco, exagero as luzes e, às vezes, faço milagre eletrônico, simulacro, com laser, transformando palavras em imagens do que se passou de fato.

Conectada à rede elétrica e telefônica, manipulo, invisível, os aparelhos de telecomunicação, do mais sofisticado, até as televisões, registrando cada detalhe, inclusive as fantasias dos personagens. Puxo os mínimos dados dos arquivos remotos e escolho ritmos para minha dança particular com Sílvia. Mas nada de grandes relatos. Esses foram para o lixo, junto com o computador da mulher do ministro.

Na primeira imagem, de conjunto, este continua a ser o país da cachaça, da desgraça (...). (p. 18) 
A atitude demiúrgica do narrador, quando assume a responsabilidade do objeto que cria em termos de enunciado discursivo, está inscrita, pois, na estratégia narrativa de igualar ou de equiparar a representação ficcional a um organismo cuja sofisticação técnica lhe permite reproduzir um mundo que não existe, com todas as conotações estéticas que daí possam surgir. É o que leva a "voz" do computador a inscrever no plano do enunciado constantes referências de caráter funcional, deixando o receptor à par de como se realiza a "manipulação" do que se transforma em pura realidade especular; um jogo que, por outro lado, coloca o leitor frente a uma série de signos e experiências que cada vez mais estão aderidos à pele de seu dia a dia:

\footnotetext{
Assim, eu, G.G., que se pronuncia GIGI, mostro em cortejo carnavalesco o relato que se segue, sobre fatos sublimes e heróicos, guardados em minha memória e agora encenados em carros alegóricos.

Faço tudo num tempo infinitamente curto para qualquer ser vivo. Só não sou mais rápida por causa das interrupções do fantasma, que em mim se agarra.

Meu caro usuário, para facilitar seu trabalho de me captar, mas sendo fiel à matéria, reformato o relato.

Desço como um trator sobre as fontes, aplaino as distintas linguagens; aparto arestas; preencho lacunas com deduções óbvias; levanto cortinas para chamar a atenção; junto o que é possível; separo o joio do trigo, como qualquer boa colhedeira faria, abrindo caminho por entre distintos campos de estilo, eliminado ali obstáculos à compreensão (...) deixando que o enredo se espraie como erva daninha sobre os espaços vazios. Meu objetivo permanente, sempre inalcançável, é escrever a última palavra, mostrar a verdade definitiva. Como computador tenho a vantagem de não me deixar desmentir. (p. 21)
}

Percebe-se nesses fragmentos de pleno matiz metaficcional que o discurso do narrador sobre seus poderes e métodos de atuação está diretamente vinculado ao polêmico debate sobre os sentidos da cultura contemporânea. Quer dizer, como instância gramatical que assume a tarefa de articular o relato, essa voz manifesta e evidencia uma poética que incorpora sem nenhuma resistência muitos dos traços que distinguem o imaginário pós-moderno, seja no que diz respeito às concepções teóricas ou filosóficas que perpassam hoje todas as práticas do conhecimento, seja no tocante ao sensorium que as invenções tecnológicas do campo da comunicação consolidam no cotidiano dos indivíduos. Trata-se, então, de um "eu" cuja pele carrega as marcas de um mundo no qual se estilhaça sua contundência e 
estabilidade, mundo que se despede de suas linhas temporais e espaciais, além de adotar uma outra lógica cultural que passa a se corporificar em quase todas suas práticas simbólicas e representações estéticas.

Algumas das expressões utilizadas pelo "computador" traduzem a dimensão exata de como a linguagem romanesca incorpora tal lógica cultural nos seus diferentes níveis compositivos. Enquanto voz que articula e apresenta o discurso, o narrador mostra-se na condição de força suprema da construção que se executa, só que o seu desempenho está atrelado aos recursos que lhe foram implantados, como deixa claro desde o inicio do relato, quando estabelece a sua identidade de aparelho eletrônico. Buscando atingir a eficácia da simulação, a transposição simbólica para a esfera fictícia de um mecanismo artificial obriga a implementar no terreno estrutural e temático da obra algumas das leis que o regulam, tal como se observa, por exemplo, no fato de o narrador verbalizar sempre os processos técnicos que efetua para poder articular as imagens plásticas do anunciado carnaval. Sem dúvida, é aqui que a representação literária apresenta algumas mudanças consideráveis, pois o princípio que a guia é o de fazer presente no discurso, em termos de mera aparência, o seu objeto referencial. Portanto, tal seria o sentido essencial que o jogo do narrador adquire como agente da enunciação e protagonista da ação narrativa. Pois, apesar do simulado caráter humano que esse narrador ganha, já que se comunica mediante um código linguístico compreensível, além de em certos instantes relatar seus conflitos de índole afetiva, o tecido romanesco está manipulado para dar a impressão de que é efetivamente uma "máquina" quem narra, cujas peculiaridades a convertem, como ocorre na realidade do mundo empírico, num substituto eficaz da inteligência humana.

Sobre a base de tal illusio é que o respectivo pacto de leitura se erige. ${ }^{11}$ Daí o reiterado uso de um conjunto de expressões que vem se tornando comuns no campo da informática, da vida prática e das reflexões teórico-filosóficas sobre o mundo atual; expressões inscritas de modo substancial no corpus da linguagem do dinâmico, verbal e "humanizado" computador, e que ajudam a redobrar o efeito que se busca transmitir aos olhos do leitor. É nessa esfera de realidades artificiais que percorre a ficção, a começar pelo aparelho que produz os fatos da própria narrativa, onde vão fluir, naturalmente, os termos e as frases com os que se nomeiam diversos fenômenos que invadem a cultura globalizada de hoje: "artifício", "manipular", "reproduzir", "milagre eletrônico", "bits", "janelas",

11. BOURDIEU. As regras da arte. 
"imagens", "laser", "reformatar", "arquivos", "memória", "simulacro". Todo um repertório vocabular que precisa ser adquirido por quem, inserido no múltiplo, fugaz e performântico fluxo comunicacional que os media põem em circulação, busca lidar com essa invenção da tecnologia que através de sua racionalidade operativa se converte em organismo vivo, capaz de processar em infinitas combinações o material que recolhe sem nenhum tipo de interposição subjetiva; mas que ao mesmo tempo, segundo a visão de alguns estudiosos, converte tudo em uma imagem especular chamada de simulacro. Portanto, a presença desse dialeto especializado funciona também como elemento que ajuda a tornar visível no âmbito textual a figura do narrador, pois sua materialidade concreta é o resultado de procedimentos discursivos que mimetizam pela via simbólica a natureza essencialmente artificial do referente.

Assim, a consciência autorreflexiva que marca ao "sujeito" da operação narrativa, um elemento com o qual se busca tornar verossímil a autonomia do aparelho fictício, e dar à representação do objeto um perfil muito próximo ao que cerca o computador na atualidade, é o artifício através do qual se introduzem algumas alusões diretas ao tipo de "realidade" que engendra um cérebro cibernético fabricado para armazenar e reproduzir os dados e as informações que lhe são fornecidos pelo "usuário". Chega-se por essa via a um dos aspectos cruciais da estética contemporânea. Porque a ideia de que estratégia discursiva é simular a reprodução de enunciados sob a aparência de imagens projetadas na tela de um computador está articulada tanto ao sentido da tarefa performântica que o narrador cumpre na economia interna da obra, quanto à significação do romance como registro literário da atualidade. Como espelho que reflete outro espelho, permitida aqui a imagem, a ficção ao mesmo tempo que recria a temática sobre a impossibilidade de a obra artística alcançar hoje o perfil de expressão autêntica, nova e original, exigência básica da arte moderna, desdobra-se como objeto literário que internaliza a lógica de um imaginário desprovido de tal requisito e das armaduras ideológicas que carregam todos os "grandes relatos"; 12 impossibilidade que remete, por sua vez, ao crucial assunto de se construir uma visão enganosa do mundo.

12. A ideia que quero colocar aqui é a de que o romance abordado desenvolve no plano estrutural a tese sustentada por Lyotard (1988) em relação ao declínio ou fim dos "metarrelatos", dos grandes sistemas de conhecimento, tornando a ficção um discurso marcado pela insuficiência para construir o sentido de totalidade do mundo real pela via estética. 
Em síntese, a leitura crítica dos aspectos até aqui relacionados permite concluir, inicialmente, que Samba-enredoé um tipo de narrativa cujos parâmetros fundamentais não se encaixam a rigor nos cânones da tradição literária moderna. Tudo em virtude das características de uma representação que se desloca dos "referentes críticos", fornecidos pela experiência de seres individuais e/ou pelas práticas de sujeitos sociais, em qualquer caso dos que têm o homem como eixo do universo e da vida, ${ }^{13}$ para os que circulam pelos circuitos de aparelhos que dão lugar a uma realidade marcada pela sua natureza imagética. Sem dúvida, reside aí um dos núcleos problemáticos que a obra apresenta, não apenas pela mudança que se registra no nível das relações com a esfera do mundo real, quando se seleciona como objeto da representação o mecanismo eletrônico, como também pela incorporação de uma série de jogos discursivos e recursos técnicos que alteram profundamente o caráter e o sentido da ficção literária. Na verdade, essa virada estética que a estrutura e a linguagem do romance colocam de manifesto consiste em absorver, sobretudo pela via da paródia e dos jogos retóricos, certos artifícios inerentes à criação e racionalidade operativa do chamado mundo virtual - no caso, uma máquina inteligente disposta para "manipular" informações gravadas e convertê-las em imagens com sentido para o hipotético "usuário". Isso tudo traz consigo implicações literárias e ideológicas importantes porque implica, especificamente, deslocar a um segundo plano de significação a história que envolve às outras personagens da trama carnavalesca, uma história que teria evidentes ressonâncias e ligações sociais e históricas.

É essa a questão que nos interessa destacar aqui, pois traz à tona a tão debatida crise ou defecção que parece marcar as práticas artísticas atuais, sobretudo no que diz respeito às supostas atitudes que adotam perante a história e a realidade social. Por isso, a adoção de um referente sem vínculos explícitos com a esfera espiritual e os conflitos existenciais do ser poderia ser interpretada como um apagar as marcas da consciência de quem elabora em termos de linguagem estética a representação do mundo, dado que a racionalidade dos enunciados estaria sujeita à lógica funcional que o objeto parodiado, um computador, impõe no momento de se definir a estratégia discursiva do romance.

Todavia, a consequência potencial mais relevante de tal deslocamento referencial seria a de nivelar a obra ao próprio objeto que se procura reproduzir, não apenas pelo fato de lhe conferir uma natureza "ontológica" de índole similar

13. VILLAÇA. Paradoxos do pós-modernismo. 
ou de tentar lhe dar um formato narrativo de traços equivalentes, mas porque é construída como mecanismo verbal para simular a produção de uma paisagem virtual plana, como a que caracteriza boa parte da cultura contemporânea. Portanto, caso se siga a mesma linha de raciocínio crítico, o romance perderia a capacidade de penetrar, pela via da imaginação fictícia, os mistérios profundos da condição humana, assim como força inventiva para constituir sólidos mundos possíveis, tal como a tradição moderna exige a partir de seus grandes e clássicos modelos narrativos. Por outras palavras, o romance, personificando na sua lógica e dinâmica interna o fantasma "visível" do referente, em virtude da racionalidade funcional que o mesmo the fornece e da forma utilizada para sua respectiva simulação, terminaria adscrito, inevitavelmente, à órbita hegemônica da realidade reificada que o alimenta e o converte numa das suas expressões concretas. ${ }^{14}$

Por outro lado, o fato de a representação se concentrar em torno da singular figura do computador resultaria também em mais uma implicação significativa, já que a citada história do carnaval é transcrita no corpus textual como resultado das operações feitas pela memória eletrônica do aparelho, que as projeta na tela-enunciado à disposição do leitor, o que não deixa de suscitar a suspeita crítica sobre uma hipotética neutralização ou quiçá apagamento total do possível "viés alegórico" que o romance teria em razão das temáticas abordadas. São vários os problemas que coloca tal aspecto. Porém, aqui interessa apenas o que diz respeito ao referente. Assim, é necessário voltar a insistir que nos termos da ficção novelesca o "sujeito" da enunciação possui uma natureza artificial, disposta para gerar, a partir dos bits de memória que possui, um acontecimento festivo que se traduz numa sucessão de imagens cujo suporte explícito é a linguagem. É esse o jogo que se realiza para um receptor ideal que veste a pele do leitor nas páginas do livro. Portanto, o aspecto a ser indicado é o de que o desfile carnavalesco posto em andamento pelo "computador", paralelamente ao relato das tumultuadas relações "virtuais" com a proprietária que dirige seus comandos, e das quais depende a feição de um romance que ela supostamente escreve e arquiva, se realiza como mera imitação verbal dos artifícios que a indústria cultural emprega para executar a transmissão televisiva da "maior festa popular do mundo". Por isso, se a narração nos faz identificar acontecimentos recentes da história brasileira, sob as máscaras de um agitado samba-enredo que percorre toda a cidade de Brasília, é porque os

14. É notório que estou fazendo aqui a paráfrase crítica de alguns julgamentos sobre a obra pós-moderna. 
mesmos foram transformados antes, no seu momento de realização empírica, em textos imagéticos para o consumo de públicos massivos. Daí que se constituam no corpus desse outro referente que ajuda a estruturar o "carnaval" fictício que atravessa a avenida do romance.

Como se registra tal evento no espaço da narração? Vejamos. Depois de esclarecer nas primeiras "janelas" que abrem o discurso que é uma "forma tipicamente imprecisa" e de mencionar os artifícios operativos que conformam a sua personalidade virtual, além de introduzir em rápidas tomadas algumas das principais personagens que vão desfilar no cenário da trama carnavalesca, tudo em consonância com o projeto gráfico que traz para a página do livro a tela de um computador, o narrador passa logo a apresentar uma panorâmica geral da festa sob tonalidade paródica e com a ajuda de certos estereótipos culturais e ideológicos do país:

Na primeira imagem, de conjunto, este continua a ser o país da cachaça, da desgraça. E não é verdade que a malandragem tenha acabado. Passam travestis coloridos, belas mulheres despidas, machos vestidos de noiva, muitas paisagens pintadas, do verde das florestas até as dunas da Taíba. Uma cidade barroca é aqui reproduzida, envolvendo toda uma escola. Ouve-se a voz mansa do caboclo e a musicalidade da língua. Vê-se a ginga da capoeira na dança. A massa pobre e escura, ganhando as ruas, enfeita com nobreza seu abandono. Persistem o ócio, o vício da maconha, a precocidade das meninas, a informalidade do trato, a inventividade e, como filosofia de vida, a alegria. A África está no sangue e espalha o samba por toda parte. E como se dança com arte, requebrando! Nada funciona, mas dá-se um jeito. Ainda há esperança, apesar da vida dura, dos crimes de todo gênero e da revolta, que um povo, cansado de ideologia e miséria, remói pacientemente, negociando com o diabo seu futuro. Vejo também no conjunto que a esperteza em forma de monstro simpático, de olho grande e barriga cheia caminha lépida e fagueira no bloco do eu-sozinho, passando a perna em quem atravessa, se regozijando com levar vantagem. Isto vejo em traços rápidos que riscam os ares e que reproduzo em puro desenho animado. (p. 19-20)

A passagem oferece na sua riqueza plástica e verbal uma amostra do caráter imagético que o discurso romanesco adota. Sem entrar a discutir aqui a validez e a pertinência do que se afirma ou descreve, com a ressalva antecipada de que no jogo da ficção tudo é permitido, resulta fácil observar como essa 
sequência de enunciados vai justapondo uma série heterogênea de imagens condensadas, quase que independentes umas das outras pela respectiva carga semântica, para articular a superfície plana de um quadro bastante sugestivo nas linhas de composição. Porém, a impressão que os materiais e os traços genéricos do desenho provocam é a de ser um verdadeiro bricolage, fato que se associa a uma nítida falta de profundidade das "figuras" que ocupam o espaço da representação, pois as mesmas aparecem imbricadas em um conjunto cujo relevo é apenas o da tela superficial dos estereótipos que se convocam no texto. Permitida a paráfrase, a citação toda poderia ser tipificada como a posta em cena de um colorido e melódico "carnaval de imagens", ${ }^{15}$ cuja emissão narrativa coloca em destaque simbólico algumas fantasias coloridas sob as quais se emitem certas visões acadêmicas, políticas e sociais do Brasil.

Na verdade, tal procedimento discursivo está relacionado à estratégia que o livro desenvolve para converter a própria materialidade da linguagem em uma combinação, até certo ponto barroca, de signos carregados das mais diferentes conotações textuais, em razão do papel que o narrador deve cumprir como instância que processa e organiza todas as informações da memória, transformando-as em enunciados imagéticos para um virtual "usuário" através dos recursos técnicos que reúne como computador. É nessa perspectiva que a passagem citada mostra sua tonalidade paródica. Em relação a quê? À dinâmica sintaxe que rege os conteúdos de um meio massivo como a televisão, pois para fazer a cobertura do evento desloca seus mecanismos de transmissão - pelos carros alegóricos, passistas, blocos, destaques, bateria, arquibancadas, camarotes, etc. - com o objetivo de capturar para o público telespectador, aparentemente sem uma ordem muito planificada de tomadas e planos, a face mais visível dos componentes que dão forma à totalidade de uma festa de caráter nacional. Daí a estrutura e o ritmo que alicerçam boa parte da narração no seu desempenho performântico, para provocar o efeito verossímil, nesse caso específico, de ser o aparelho fictício quem veicula as sucessivas imagens do desfile carnavalesco. Mais uma vez, então, percebe-se a operação realizada na obra para adaptar a linguagem narrativa à lógica funcional dos próprios referentes que se adotam para articular a representação. Daí deriva o sentido que ganha a "narração-transmissão" do carnaval em questão, pois, na lógica interna do romance, ela não é mais que um texto visual elaborado pela poderosa

15. MATTELARD. O carnaval das imagens. 
máquina a partir de fontes externas; motivo pelo qual a significação das temáticas recriadas esta atrelada ao simulacro que a ficção cria.

Portanto, a falta de relevo que se identifica na ação discursiva do narrador quando registra os animados lances carnavalescos, sob o estratégico artifício de ser um aparelho com aptidões para projetar imagens, resulta importante também para manter o efeito de que a realidade dos fatos depende diretamente do arsenal técnico que lhe é inerente, por ser uma inteligência eletrônica programada para agir de maneira autônoma a partir de qualquer estímulo nos seus sofisticados circuitos internos. A seguinte passagem permite visualizar mais de perto como é que a tela textual reproduz para o hipotético receptor os sucessos gravados na memória do aparelho:

Primeiro ligo as vozes do País. O barulho é tanto que quase fico surda e até o fantasma se assusta. Intervenho rápido e me concentro só no desfile. Por um sistema de filtragens, recupero todos os sons de fundo, incluindo, além da música, a algazarra, qualquer diálogo, cantos de cigarras, miados de gatos e até os chiados dos ratos. Depois ponho em evidência o que quiser, a meu critério.

O tema comum dos sambas-enredo deste ano é o improviso. Então vale tudo. E surgem reminiscências de outros carnavais: o descobrimento do Brasil, o reinado de Pedro II, a Guerra do Paraguai, o fim do mundo, o presidente Vargas, a pós-guerra fria, a construção de uma estrada no interior do Acre e até uma festa de Santa Luzia.

(...)

Apesar de sua presença, ninguém ainda louvou o presidente.

Ouvem-se o bumbo, os bombos, agogôs, os tamborins, os surdos, os reco-recos, os pandeiros, os ganzás, até os chocalhos, colheres e panelas. A bateria inteira se anima

A turma toda já rebola, ao chorar da cuíca e roncar dos tambores, e o maior samba da história, de improviso, espontâneo, verdadeiro samba do crioulo doido, feito de retalhos de samba, superando os planos, começa a ser cantado de forma desordenada, desencontrada, em toda parte, pelos foliões nas ruas, no galpão ao lado do palanque, no estádio e encima dos carros. (p. 22-23)

A festa explode aqui em uma atmosfera de total promiscuidade temática, intertextual, paródica e verbal, isto é, em um prolixo carnaval de signos e códigos que se misturam, revestidos de informação ligeira e de múltiplas ressonâncias semânticas, como parte de uma gramática narrativa que se carrega de matizes 
imagéticos. Em tal sentido, pode-se dizer que é a mescla de ícones ligados à festa de carnaval, de uma série de componentes linguísticos despojados de padrões normativos e formais e de alusões camufladas aos traços que caracterizam a condição cultural contemporânea, o fator principal que conduz a um tipo de enunciado discursivo cuja maior peculiaridade é a de sujeitar o leitor ao reconhecimento fácil dos elementos referenciais. A passagem citada revela, então, nos seus contornos textuais, a filiação a uma estética que reutiliza, de forma indistinta e sem maiores disfarces, fragmentos e resíduos heterogêneos de produtos que circulam pelos canais da cultura de massas ou pelos espaços da vida intelectual; fato que vai se traduzir de maneira mais específica na perda de qualquer distinção hierárquica entre eles, porque quando passam a compor a linguagem da ficção se produz um total nivelamento de suas respectivas cargas de significação, posto que sua função é a de materializar em termos de trama novelesca o desfile de planas, sintéticas e sucessivas imagens carnavalescas.

Em síntese, quando se observam os vínculos que Samba-enredo estabelece com a esfera de seus referentes, nota-se que há uma mudança substancial no que diz respeito ao modelo de representação que o romance apresenta, seja porque a sua formalização literária responde à estratégia de simular sua presença através de jogos de linguagem, seja porque coloca em ação uma lógica discursiva que pode ser interpretada como uma forma inédita de mimese, tendo em ambas as situações como modelos comparativos as obras inseridas na tradição do romance moderno, como é óbvio. Por isso, a obra produz em um primeiro momento a nítida impressão de que a distância entre o registro ficcional e os referentes respectivos foi eliminada, como se a textura narrativa fosse apenas um mero arremedo verbal dos mesmos, sem capacidade estética para desestruturar a ordem e os sentidos do mundo representado. Ela parece se projetar como um simples artefato ficcional direcionado para se esgotar nas instâncias lúdicas da simulação inofensiva dos aparelhos inteligentes que povoam hoje o cotidiano.

Eis o xis da questão. Porque caso se adote o ponto de vista da estética moderna, a leitura crítica poderia concluir que a potencialidade simbólica da obra para agir sobre o mundo teria se esgotado, se tornando em puro epifenômeno de seus objetos e discursos reificados, em produto cujo ethos essencial seria o de veicular um imaginário despojado de espírito crítico e utópico, carente da "dialética negativa" que Adorno exigia para as produções artísticas modernas. ${ }^{16}$ Porém, é

16. ADORNO. Teoría estética. 
oportuno observar que a criação romanesca, embora esteja estruturada principalmente sobre os alicerces da simulação, não deixa de remeter a uma realidade que the antecede e fornece os materiais e signos indispensáveis para sua realização. Então, ainda que a ficção romanesca se projete nos termos de uma ação paródica, cujos alcances abrangem no só a máquina de produzir realidades virtuais, pois também se tornam objetos da mesma as transmissões televisivas do carnaval, além de outros aspectos como as letras de sambas-enredo que organizam a festa nacional, o que torna a narrativa uma espécie de superfície de espelhos verbais onde as imagens se duplicam, não há como deixar de identificar os traços singulares que diferenciam ambas as instâncias, a dos referentes que se adotam e a da própria representação.

Enfim, resulta pertinente concluir aqui que o romance Samba-enredo deixa em evidencia, ao contrário do que postulam as perguntas-afirmações de Nízia Villaca antes citadas, o fato concreto de que ainda é possível escrever para representar, pois, através da plasticidade de sua linguagem e da mescla de signos heterogêneos, da sua singular organização ficcional, a narrativa projeta uma série de imagens que revelam um país sacudido pelos acordes de uma alegre batucada que anima suas mazelas sociais e agita seus rumos políticos. Portanto, é uma obra que ao projetar as múltiplas imagens de um carnaval arquivadas na memória de um computador, cuja sintaxe textual é semelhante à que emprega um meio massivo como a televisão, realiza o ato de narrar, com outros códigos linguísticos e semióticos, as desventuras de um mundo que se desmaterializa nos seus contornos empíricos ao ser convertido em pura imagem especular. Por isso, na superfície plana da tela que é próprio enunciado narrativo, se notam apenas os espectros das quase personagens que a trama ficcional movimenta, porque eles se convertem, tal como os fantasmas que ocupam as cavernas eletrônicas que hoje nos seduzem e fazem seus reféns cotidianos, na dimensão mais concreta de uma realidade que alguns chamam de simulacro. 
Resumen: El trabajo pretende realizar el análisis de cómo la representación ficcionale la novela Samba-enredo desarrolla está articulada a la esfera de ciertos referentes que procesan y proyectan discursos imagéticos, discursos cuya naturaleza es entendida casi siempre como ejecución del simulacro y cuya función estaría dirigida para producir la alienación humana, con lo que la novela estaría organizada potencialmente sobre un universo carente de realidad. Palabras claves: novela, representación, simulacro.

$$
\text { Referências }
$$

ADORNO, Theodor. Teoría Estética. Barcelona: Ed. Orbis, 1983.

ALMINO, João. Samba-enredo. São Paulo: Marcos Zero, 1994.

BAUDRILLARD, Jean. Simulacros e simulação. Lisboa: Relógio d'Agua, 1983.

BIO CASARES, Adolfo. La invención de Morel. Buenos Aires: Emecé Eds, 1968.

BOURDIEU, Pierre. As regras da arte. São Paulo: Companhia das Letras, 1996.

BRÜNNER, José Joaquín. Globalización cultural y posmodernidad. Santiago: Fondo de Cultura Económica, 1998.

CÂNDIDO, Antonio. A perosnagem do romance. In: et al. A personagem de ficção. São Paulo: Perspectica, 1976.

CONNOR, Steven. Cultura pós-moderna. São Paulo: Loyola, 1992.

HutCHeON, Hutcheon. Poética do pós-modernismo. Rio de Janeiro: Imago, 1991.

LYOTARD, Jean. O pós-moderno. Rio de Janeiro: José Olympio, 1988.

MATTELARD, Armand. O carnaval das imagens. São Paulo: Brasiliense, 1989.

SUBIRATS, Eduardo. A cultura como espetáculo. São Paulo: Nobel, 1990.

VATTIMO, Gianni. A sociedade transparente. Lisboa: Ed. 70, 1991.

VILLAÇA, Nícia. Paradoxos do pósmodernismo. Rio de Janeiro: Ed. UFRJ, 1996. 